\title{
Genetics of Late-Onset Alzheimer's Disease: Update from the Alzgene Database and Analysis of Shared Pathways
}

\author{
Paolo Olgiati, ${ }^{1}$ Antonis M. Politis, ${ }^{2}$ George N. Papadimitriou, ${ }^{2}$ \\ Diana De Ronchi, ${ }^{1}$ and Alessandro Serretti ${ }^{1}$ \\ ${ }^{1}$ Institute of Psychiatry, University of Bologna, Viale Carlo Pepoli 5, 40123 Bologna, Italy \\ ${ }^{2} 1$ st Department of Psychiatry, National and Kapodistrian University of Athens Medical School, Eginition Hospital, \\ 10679 Athens, Greece
}

Correspondence should be addressed to Alessandro Serretti, alessandro.serretti@unibo.it

Received 14 January 2011; Accepted 21 September 2011

Academic Editor: Francesco Panza

Copyright () 2011 Paolo Olgiati et al. This is an open access article distributed under the Creative Commons Attribution License, which permits unrestricted use, distribution, and reproduction in any medium, provided the original work is properly cited.

\begin{abstract}
The genetics of late-onset Alzheimer's disease (LOAD) has taken impressive steps forwards in the last few years. To date, more than six-hundred genes have been linked to the disorder. However, only a minority of them are supported by a sufficient level of evidence. This review focused on such genes and analyzed shared biological pathways. Genetic markers were selected from a web-based collection (Alzgene). For each SNP in the database, it was possible to perform a meta-analysis. The quality of studies was assessed using criteria such as size of research samples, heterogeneity across studies, and protection from publication bias. This produced a list of 15 top-rated genes: APOE, CLU, PICALM, EXOC3L2, BIN1, CR1, SORL1, TNK1, IL8, LDLR, CST3, CHRNB2, SORCS1, TNF, and CCR2. A systematic analysis of gene ontology terms associated with each marker showed that most genes were implicated in cholesterol metabolism, intracellular transport of beta-amyloid precursor, and autophagy of damaged organelles. Moreover, the impact of these genes on complement cascade and cytokine production highlights the role of inflammatory response in $\mathrm{AD}$ pathogenesis. Gene-gene and gene-environment interactions are prominent issues in $\mathrm{AD}$ genetics, but they are not specifically featured in the Alzgene database.
\end{abstract}

\section{Introduction}

Alzheimer's disease $(\mathrm{AD})$ is the leading cause of dementia in developed countries. It afflicts 5.3 million individuals in the US. Total direct and indirect cost is US\$ 172 billion per year [1]. The prevalence of AD shows an age-dependent progression in the elderly. Thus, approximately $5 \%$ of all persons over age 70 have $\mathrm{AD}$ (late-onset $\mathrm{AD}, \mathrm{LOAD}$ ); this proportion raises to $25 \%-45 \%$ in "oldest old" ( $>85$ years) individuals. About $10 \%$ of $\mathrm{AD}$ patients develop symptoms before age 65 , more often in their $40 \mathrm{~s}$ or $50 \mathrm{~s}$ [1].

Clinically, $\mathrm{AD}$ is characterized by progressive impairments in memory and other cognitive domains. Behavioral and psychiatric symptoms (BPSDs), clustered into agitation/aggression, mood disorders, and psychosis, may occur with disease progression [2]. Neuroimaging studies display atrophy in the cerebral cortex and the hippocampus of $\mathrm{AD}$ brain $[3,4]$. A marked neural loss is reported in cholinergic nuclei in the basal forebrain as opposed to an overactivation of NMDA-mediated glutamatergic pathways [5]. Postmortem examination reveals the neuropathological hallmarks of $\mathrm{AD}$ that include neuritic plaques, neurofibrillary tangles (NFTs), and amyloid angiopathy [6]. Neuritic plaques are extracellular aggregates of beta $(\beta)$-amyloid protein in a milieu of reactive astrocytes and activated microglia. NFTs are intraneuronal cytoplasmatic filaments composed of hyperphosphorylated tau, frequently conjugated with ubiquitin. Pathophysiologically, researchers assign a pivotal role to beta-amyloid deposition in the brain [6]. Betaamyloid peptides are derived from proteolytic activity of proteinases ( $\beta$ and $\gamma$ secretases) on amyloid precursor protein (APP). Study performed in transgenic animals suggest that neuroinflammation plays an important role in the process of cerebral amyloid deposition [7]. It has been shown that 
inflammatory cytokines such as interleukin (IL)-1 $\beta$, IL-6, tumor necrosis factor- $\alpha$ gTNF- $\alpha$ ), or IFN gamma can augment APP expression and $A \beta$ formation $[8,9]$. It was also reported that nonsteroidal anti-inflammatory drugs are able to transcriptionally upregulate $\beta$-secretase mRNA, protein and enzymatic activity [10]. Intraperitoneal injection of lipopolysaccharide induced memory impairment in mice associated with amyloidogenesis [11]. On the other hand, recent lines of evidence indicate that blood-borne mononuclear phagocytes are capable of infiltrating the brain and restricting beta-amyloid plaques, thereby, limiting disease progression. Indeed, there would be two types of monocytes. M1 has proinflammatory effects detrimental to $\mathrm{AD}$ brain. Alternately, M2 macrophages are recruited to noninflamed tissues and are believed to be highly phagocytic, antiinflammatory effector cells. They could clear beta amyloid via phagocytosis [12]. APP follows a complex intracellular trafficking pathway that influences its processing to either a soluble fragment $(\operatorname{sAPP} \alpha)$ or to $\operatorname{sAPP} \beta$ and the insoluble $\mathrm{A} \beta$ [13]. The cleavage of APP to generate pathological $A \beta$ may occur when APP transits from the endosome to the lysosome. This is associated with APP gene mutations, whereas wild APP has rapid and direct transport from the cell surface to the lysosomes [14]. APP trafficking is regulated by sortingprotein-related receptor (sorLA), which binds the APP in the Golgi reducing the availability of precursors for transport, cleavage, and transformation into $\mathrm{A} \beta[15,16]$. Over the last few years, a shift occurred in research focus from amyloid deposition to tauopathy. The physiological function for protein tau is binding to and stabilization of microtubules. Microtubules ensure cell shape and constitute roads of transport. Microtubule-dependent transport is ensured by families of motor proteins dyneins and kinesins, respectively, for retrograde transport from distal processes towards soma and as plus-end directed motor for anterograde transport. The effect of protein tau on transport appears to be dual. First, hyperphosphorylation can cause protein tau to detach from the microtubules and decrease its ability to control microtubule dynamics. On the other hand, increased levels of protein tau can saturate microtubules and hinder the "foot-stepping" of the motor proteins needed for axonal and dendritic transport. Both aspects of tau-related transport deficits have been observed and both can fit into a model leading to "starving synapses" that eventually culminates in neuronal death $[17,18]$. It is acknowledged that $75 \%$ of people with $\mathrm{AD}$ have sporadic $\mathrm{AD}$. This is most likely a multifactorial condition, which involves a combination of genetic, lifestyle, and environmental factors. $25 \%$ is familial $\mathrm{AD}$ (FAD). Early-onset $\mathrm{AD}$ encompasses $5 \%$ of FAD cases. Early-onset FAD is inherited in an autosomal dominant manner and is caused by mutations in one of these three genes: APP, PSEN1, and PSEN2. As for LOAD, the only established genetic factor is apolipoprotein E (APOE). The APOE gene is at chromosome location 19q13.2. APOEassociated Alzheimer's disease is due to a specific variation in the APOE gene called e4 allele. It is estimated that 40 $65 \%$ of AD patients have at least one copy of the e 4 allele [19]. Individuals with two e4 alleles have up to 20 times the risk of developing AD [19]. Another variant of the APOE gene, e2, has protective effects against the development of $\mathrm{AD}$ $[20,21]$. Nonetheless, a third of patients with AD are ApoE4 negative, and some ApoE4 homozygotes never develop the disease. Since the early $90 \mathrm{~s}$, more than six hundred genes have been investigated as susceptibility factors for LOAD (http://www.Alzgene.org/). We reviewed the best established LOAD genes and suggested a method to identify shared biological pathways.

\section{Methods}

We used the AlzGene database to identify those genes that had the strongest association with LOAD, for which there was a qualitatively high level of evidence. AlzGene is a web-based synopsis of published association studies on $\mathrm{AD}$ [22]. AlzGene is regularly updated by studies retrieved from peer-reviewed journals and available in English language. Authors are encouraged to submit their data as soon as their work is accepted for publication. Data presented only in abstract form are not included. For all polymorphisms with minor allele frequencies in healthy controls $>1 \%$, and for which case-control genotype data are available in at least four independent samples, a meta-analysis is performed. Summary OR and 95 percent CIs are calculated using the DerSimonian and Laird random-effects model [23]. Genes which contain variants showing at least one significant OR in meta-analysis are included in a "Top Results" list. To establish their ranking, each positive meta-analysis is graded according to human genome epidemiology network (HuGENet) interim criteria for the assessment of cumulative evidence of genetic associations [24]. These criteria take into account the amount of evidence (sample size, measured as total number of minor alleles of cases and controls combined in the meta-analysis " $N$ minor"; grade A: $N$ minor exceeds 1,000; grade B: $N$ minor is between 100 and 1,000; grade C: $N$ minor is $<100$ ), consistency of replication (heterogeneity across studies, measured as I2; grade A: I2 point estimates $<25 \%$; grade B: between $25 \%$ and $50 \%$; grade C: $>50 \%$ ) and protection from bias (the following potential reasons for bias in the meta-analysis results are assessed: summary OR $<1.15$ (low OR); loss of significance after exclusion of first study; loss of significance after exclusion of studies with deviations from HWE in control groups; evidence for publication bias; grade A: no bias; grade B: no demonstrable bias, but important information is missing for its appraisal; grade C: evidence for clear bias that can invalidate the association). Overall epidemiologic credibility is graded as "A" (= strong) if associations received three A grades, "B" (= moderate) if they received at least on $\mathrm{B}$ grade but no $\mathrm{C}$ grades, and "C" (= weak) if they received a $\mathrm{C}$ grade in any of the three assessment fields. Loci with the same grade are ordered by $P$-value.

Genes with strong (A) and moderate (B) associations were included in a query set of the gene ontology database AmiGO to discover shared biological functions. The Gene Ontology [GO (http://www.geneontology.org/); Gene Ontology Consortium, 2000] project develops structured controlled vocabularies, or ontologies, to describe 
fundamental characteristics of genes and their products in a species-independent manner. Members of the GO consortium submit annotations made using these ontologies to the GO database for integration and dissemination. AmiGO (version 1.7) (http://amigo.geneontology.org/) is a web-based application that allows users to search, sort, analyze, visualize, and download data about gene ontologies and products [25]. Ontologies are clustered into three categories: (1) biological process: any process specifically pertinent to the functioning of integrated living units: cells, tissues, organs, and organisms. A process is a collection of molecular events with a defined beginning and end; (2) cellular component: the part of a cell or its extracellular environment in which a gene product is located. A gene product may be located in one or more parts of a cell, and its location may be as specific as a particular macromolecular complex, that is, a stable, persistent association of macromolecules that function together. (3) Molecular function: elemental activities describing the actions of a gene product at the molecular level. A given gene product may exhibit one or more molecular functions. The GO "Term Enrichment" tool, which determines whether the observed level of annotation for a group of genes (test dataset) is significant in the context of a background set, was useful for discovering relationships between genes. We included LOAD genes in test dataset; the UniProt Knowledgebase (UniProtKB: http://www.uniprot.org/), a large collection of gene products, was used as comparison dataset. Significant annotations were associated with at least two genes and more represented in test dataset $(P=0.003$ after Bonferroni correction). Subsequently, the GO slimmer tool enabled to remap granular, specific annotations up to a userspecified set of high-level terms. We excluded terms that were nonspecific (e.g., "biological regulation") or shared by less than three genes. Synonymous annotations (e.g., "cell death" and "regulation of cell death") were collapsed into one term.

\section{Results}

The Alzgene database (updated 13 September 2010) includes 1,380 studies and 666 genes. The number of meta-analyses is 380 .

3.1. Top Genes Associated with LOAD. Forty-two genes have at least one positive meta-analysis (see Table 1). Of them, fifteen are supported by an adequate level of evidence ("A" or " $\mathrm{B}$ " grade on overall association credibility). These genes are reported below (meta-analysis results are referred to the best SNP for each gene).

APOE. The gene encoding apolipoprotein E (chromosome $19 q$ 13.2) was associated with AD in thirty-eight case-control samples $($ Caucasian $=28 ;$ Asian $=4$; African descent $=2$; Hispanic descent $=1$; mixed ethnic groups $=3$ ) and four family-based studies. Overall OR was 3.77 (95\% CI 3.294.32; $\left.\mathrm{I}^{2}=13\right)$ in Caucasian samples and 3.99 (95\% CI: 2.86$\left.5.57 \mathrm{I}^{2}=20\right)$ in Asian samples.

$C L U$. Clusterin (apolipoprotein $\mathrm{J}$ ) is a chaperone molecule that appears to be involved in membrane recycling and apoptosis. Clusterin, like apolipoprotein E, is found in amyloid plaques [26]. Clusterin interacts with the soluble form of beta amyloid in animal models of $\mathrm{AD}$ and binds soluble beta-amyloid in a specific and reversible manner, forming complexes that cross the blood-brain barrier [27]. The gene-encoding clusterin CLU (chromosome 8) was investigated as a susceptibility factor for LOAD in genomewide association studies (GWASs) [28-32] as well as candidate gene studies [33, 34]. Meta-analytic data reveal four polymorphisms consistently associated with LOAD. The best SNP is rs11136000 (Caucasian subjects; $N$ minor $=$ 53,712; OR 0.88 95\% CI: 0.86-0.91). Valproic acid has been recently demonstrated to stimulate clusterin expression [35]. Plasma levels of clusterin have been recently associated with atrophy of the entorhinal cortex, baseline disease severity, and rapid clinical progression in $\mathrm{AD}$ [36]. These findings should prompt further investigations to ascertain the impact of CLU on AD phenotypes.

PICALM. Phosphatidylinositol-binding clathrin assembly proteins is a key component of clathrin-mediated endocytosis. It recruits clathrin and adaptor protein 2 (AP-2) to the plasma membrane and, along with AP-2, recognizes target protein. The attached clathrin triskelions cause membrane deformation around the target proteins enclosing them within clathrin-coated vesicles [37]. Of relevance to $\mathrm{AD}$, PICALM appears to be involved in VAMP2 trafficking, a process that is crucial to the functional integrity of synapses. [38]. AD brains show a reduced number of synapses, and this reduction could correlate to cognitive defects better than the accumulation of plaques and tangles [39]. Alternatively, APP is processed in endocytotic compartments [40]; thus PICALM could promote the synthesis of beta amyloid by regulating endocytosis. The PICALM gene (chromosome 11) was analyzed in seven case-control samples [29-31, 33, 41, 42]. Overall PICALM was investigated in 10,251 patients and 18,270 controls. Two SNPs were associated with LOAD. The best one is rs3851179 (Caucasian subjects; $N$ minor $=44,358$ OR 0.88 95\% CI: 0.85-0.91).

EXOC3L2. Exocyst complex component 3-like 2 is also involved in vesicle targeting during exocytosis of proteins and lipids that is essential to neuron outgrowth and integrity [43]. Seshadri et al. [30] reported an association between the EXOC3L2 gene and LOAD in their multisample GWAS which included 1,140 patients and 1,210 controls (rs597668 $N$ minor $=13,519$ OR 1.17 95\% CI: 1.12-1.23).

BIN1. Bridging integrator 1 is a member of the BAR adapter family which has been implicated in endocytosis and intracellular endosome trafficking $[44,45]$. In addition, bin1 is crucial for the function of pathways leading to cell senescence and apoptosis [46-48]. The BIN1 gene (chromosome 2) was investigated in four case-control samples [29, 30, 41] consisting of 4,473 patients and 7,659 controls. A metaanalysis showed that BIN1 rs $744373 \mathrm{SNP}$ was associated with LOAD ( $N$ minor $=24,713$ OR 1.15 95\% CI: 1.101 .20 ).

CR1. Complement component receptor 1 regulates complement cascade via the inhibition of both classical and 
TABLE 1: Top-rated genes associated with LOAD.

\begin{tabular}{|c|c|c|c|c|c|c|}
\hline Gene & $\mathrm{Ch}$ & $\mathrm{N}^{\circ}$ minor & $\begin{array}{c}\text { Quality } \\
\text { (HuGENet) }\end{array}$ & $\begin{array}{c}\text { Caucasian } \\
\text { OR } \\
\end{array}$ & $\begin{array}{c}\text { Asian } \\
\text { OR } \\
\end{array}$ & $\begin{array}{c}\text { All ethnic groups } \\
\text { OR }\end{array}$ \\
\hline APOE & 19 & 4,167 & $\mathrm{AAA}$ & $3.77(3.29-4.32)$ & $3.99(2.86-5.57)$ & $3.61(3.20-4.08)$ \\
\hline CLU & 8 & 53,712 & $\mathrm{AAA}$ & $0.87(0.85-0.90)$ & n.a & $0.88(0.86-0.91)$ \\
\hline PICALM & 11 & 44,358 & $\mathrm{AAA}$ & $0.89(0.86-0.92)$ & n.a & $0.90(0.86-0.93)$ \\
\hline EXOC3L2 & 19 & 13,519 & AAA & $1.17(1.12-1.23)$ & n.a & $1.17(1.12-1.23)$ \\
\hline BIN1 & 2 & 24,713 & AAA & $1.14(1.08-1.21)$ & n.a & $1.14(1.08-1.21)$ \\
\hline CR1 & 1 & 18,779 & AAA & $1.14(1.08-1.20)$ & n.a & $1.16(1.09-1.22)$ \\
\hline SORL1 & 11 & 1,734 & AAA & $1.07(1.00-1.15)$ & $1.30(1.13-1.50)$ & $1.10(1.02-1.17)$ \\
\hline TNK1 & 17 & 3,538 & AAA & $0.84(0.76-0.93)$ & n.a & $0.84(0.76-0.93)$ \\
\hline IL8 & 4 & 1,157 & AAA & $1.26(1.01-1.58)$ & n.a & $1.26(1.01-1.58)$ \\
\hline LDLR & 19 & 1,228 & AAA & $0.85(0.72-0.89)$ & n.a & $0.85(0.72-0.89)$ \\
\hline CST3 & 20 & 1,203 & AAA & $1.28(1.04-1.56)$ & n.a & $1.23(1.03-1.48)$ \\
\hline CHRNB2 & 1 & 227 & BAA & $0.69(0.51-0.95)$ & n.a & $0.67(0.50-0.90)$ \\
\hline SORCS1 & 10 & 567 & $\mathrm{BAA}$ & $1.34(1.09-1.65)$ & n.a & $1.34(1.09-1.65)$ \\
\hline TNF & 6 & 301 & BAA & n.a & $1.37(1.05-1.79)$ & $1.35(1.39-1.77)$ \\
\hline CCR2 & 3 & 308 & $\mathrm{BAA}$ & $0.73(0.56-0.97)$ & n.a & $0.73(0.56-0.97)$ \\
\hline
\end{tabular}

OR values are referred to the best SNP for each gene.

n.a: one study or none; meta-analysis could not be performed.

HuGENet classification was used to assess the quality of studies (see text).

alternative pathway C3 and C5 convertases [49]. Notably, complement inhibition was shown to reduce the clearance of beta amyloid in animal models [50]. More recently, cr1 has been found to bind peripheral blood beta amyloid in a complement $\mathrm{C} 3 \mathrm{~b}$-dependent manner, a mechanism that is implicated in the clearance of pathogens and proteins from the bloodstream. Levels of beta amyloid targeted by this pathway differed significantly in $\mathrm{AD}$ compared to mild cognitive impairment and nondemented elderly controls [51]. The gene encoding crl, chromosome 1 (CR1), was investigated in eleven independent samples [28, 29, 31, 33, $41,42,52]$. Overall sample included 13,193 cases and 20,551 controls. Meta-analytic data showed the association between CR1 rs3818361 and LOAD in Caucasian subjects $(N$ minor $=$ 18, 779 OR 1.14 95\% CI: 1.08 1.20).

SORL1. Sortilin-related receptor (SorLA) is a sorting receptor that regulates trafficking and processing of APP. SorLA acts as a retention factor for APP in trans-Golgi compartments/trans-Golgi network, preventing the release of the precursor into regular processing pathways $[16,53]$. In addition, SorLA is an apolipoprotein E receptor (LR11). The gene-encoding SorLA, SORL1, was investigated as a susceptibility factor for LOAD in twenty-one case-control samples [54-74]. Nine SNPs were significantly associated with LOAD. The best one is rs2282649 ( $N$ minor $=1,734$ OR $1.1095 \%$ CI: 1.02-1.17). A recent study has suggested that the role of SORL1 as a LOAD gene might be gender dependent, consistently demonstrated in women [67]. We confirmed this result in a sample of AD patients attending our center in Athens. In addition, we reported correlations between SORL1 SNPs, psychosis, and proinflammatory cytokines [75].

TNK1. Nonreceptor tyrosine kinase 1 is involved in intracellular transduction pathways, and it was shown to enable
TNF-alpha-induced apoptosis [76]. One polymorphism (rs1554948) in the TNK1 gene (chromosome 17) was investigated in five samples [77], and it proved its association with LOAD (rs1554498; $N$ minor $=3,538$; OR $0.8495 \% \mathrm{CI}$ : 0.76-0.93).

IL8. Interleukin 8 is a proinflammatory cytokines. Cerebrospinal fluid levels of IL- 8 were found to be increased in $\mathrm{AD}$ and mild cognitive impairment [78]. IL- 8 production can be enhanced by beta amyloid [79]. The gene-encoding IL-8 (chromosome 4) was analyzed in four case-control samples [32, 80-82], including 660 patients and 933 controls, and it proved to be significantly associated with LOAD (rs4073; $N$ minor = 1,157; OR 1.27 25\%CI: $1.08-1.50)$. IL8 showed gene-gene interactions with the methylenetetrahydrofolate reductase (MTHFR) [82] and interleukin-1alpha (ILalpha) [80] genes. Metal ions (zinc; copper) appear to play an important role in $\mathrm{AD}$ pathophysiology. For instance, the provision of a zinc-enriched diet was found to enhance Alzheimer-like spatial memory impairments in transgenic mice and to modify hippocampal deposits of amyloid plaques [83]. Zinc ions promote beta-amyloid aggregation leading to conformational changes [84]. A consistent amount of evidence links zinc and IL8 pathways. Zinc deficiency increases the expression of cytokine-related genes (TNF; IL1B; IL8) in leukemia cell-lines. Elevated levels of proinflammatory cytokines including IL- 8 were reported in a group of healthy old subjects coupled with low circulating levels of zinc [85]. Traumatic brain injury, a known risk factor for $\mathrm{AD}$ development [86], can modify the expression of proinflammatory cytokines [87].

$L D L R$. Low density lipoprotein receptor is implicated in cholesterol metabolism via endocytosis. Recently, it has been discovered that overexpression of brain LDLR is associated 
with decrease in APOE levels and beta amyloid due to either inhibited deposition or enhanced clearance [88]. Moreover, two members of the LDLR family were found to modulate APP trafficking [89]. The LDLR gene is localized to chromosome 19. Its association with LOAD was explored in twelve studies [32, 52, 90-99]. A polymorphism (rs 5930) showed a consistent association with $\mathrm{LOAD}(N$ minor $=1,228$; OR 0.85 95\% CI: 0.72-0.99). Zou et al. reported a sex modulation of $L D L R$ gene that was linked to LOAD in male subgroup [99].

CST3. Cystatin C, a potent inhibitor of lysosomal proteinases, was shown to bind beta amyloid and to prevent beta-amyloid aggregation and deposition in mouse models [100]. More recently, cystatin levels have been positively correlated with beta-amyloid and tau protein in cerebrospinal fluid of individuals with $\mathrm{AD}$, mild cognitive impairment, and healthy controls [101]. The gene-encoding cystatin, chromosome 20 (CST3), was associated with dementia in Lewy body disease. The association between CST3 and LOAD was analyzed in fourteen Caucasian [32, 52, 72, 96, 102-111] and four Asian studies [112-115]. Overall Caucasian sample included 2,502 patients and 1,897 controls. Overall Asian sample included 814 patients and 1,293 controls. Two CST3 polymorphisms were associated with LOAD in Caucasian groups. The best one is rs1064039 $(N$ minor $=1,203$; OR 1.16 95\% CI: $1.00-1.33$ ).

CHRNB2. Each nAChR protein is made up of a combination of five subunits, usually two alpha $(\alpha)$ and three beta $(\beta)$ subunits. Many different combinations are possible, and the characteristics of each $\mathrm{nAChR}$ protein depend on which subunits it contains. In the brain, nAChR proteins most commonly consist of two $\alpha 4$ subunits and three $\beta 2$ subunits. The CHRNB2 gene (chromosome 1) is responsible for producing the $\beta 2$ subunit. A wide range of brain functions depend on nAChR channels, including sleep and arousal, fatigue, anxiety, attention, pain perception, and memory. The channels are also active before birth, which suggests that they are involved in early brain development. The association between CHRNB2 and LOAD was originally investigated in an Asian sample of 58 patients and 51 controls with negative results [116]. Three Caucasian studies followed the first one [117-119]. Cook et al. analyzed three samples and reported a significant association with $\mathrm{LOAD}(N$ minor $=227$; OR 0.69 95\% CI: 0.51-0.95).

SORCS1. SorCS proteins (like SorLA) are members of the Vps10p family of sorting receptors. SorCS1 binds to nerve growth factor (NGF) propeptide. Pro-NGF is increased in $\mathrm{AD}$ brains, and its binding to neurotrophin receptor $\mathrm{p} 75$ induces apoptotic cell death in neurons [120]. In addition, SorCS1 was involved in APP processing [121]. The geneencoding SorCS1, SORCS1 (chromosome 10), has been associated with insulin signaling and diabetes mellitus [122]. Grupe et al. [77] reported an association between SORCS1 and LOAD in four Caucasian samples (rs600879; $N$ minor = 567; OR 1.34 95\% CI: 1.09-1.65). A family-based study showed an association between SORCS1 and LOAD in a women subgroup [123].
TNF. Tumor necrosis factor alpha induces the production of beta amyloid [9], and it increases the risk of developing $\mathrm{AD}$ in cognitively intact elderly subjects [124]. The gene-encoding TNF (chromosome 6) has been extensively investigated as a susceptibility AD gene. One SNP (rs4647198) was significantly associated with LOAD in Asian populations [125-127] $(N$ minor $=301$; OR 1.37 95\% CI: 1.05-1.08). Increase in the serum levels of TNF-alpha following acute inflammatory events was found to correlate with a 2 -fold increase in the rate of cognitive decline over a 6-month period in $\mathrm{AD}$ patients. In addition, the rate of cognitive decline was four fold increased in patients with high basal levels of TNFalpha [128]. Etanercept, a biological antagonist of TNFalpha, is under evaluation as a therapeutic agent for AD. A rapid improvement in cognitive performance was reported following etanercept administration in a pilot study [129].

CCR2. Chemokine receptor 2 is IL-8 receptor. It is coupled with MAP-kinase pathway to modulate signaling transduction. CCR2 gene (chromosome 3 ) was associated with LOAD in Caucasian samples $[32,130,131](\mathrm{rs} 1799864 ; N$ minor $=$ 308; OR 0.73 95\% CI: 0.56-0.97).

3.2. Shared Biological Pathways. Gene ontology analysis identified 146 GO terms more represented in test dataset (LOAD genes) than in UniProtKb collection $(P<0.001)$. Most of them were excluded or collapsed based on criteria reported above. The following terms were selected: "immune system process" (TNF, IL8, CR1, CLU, CCR2, PICALM, and CHRNB2); "vesicle-mediated transport" (PICALM, SORL1, $A P O E, B I N 1, L D L R$, and CLU); "cellular membrane organization" (SORL1, APOE, PICALM, BIN1, and LDLR); "alcohol metabolic process" (CHRNB2, SORL1, APOE, TNF, and $L D L R$ ); "lipid transport" (SORL1, APOE, LDLR, CLU, and TNF); "steroid metabolic process" (SORL1, APOE, TNF, and LDLR); "cholesterol metabolic process" (APOE, CLU, $L D L R$, and SORL1); "cell death/apoptosis" (APOE, TNF, and $C L U)$; "cell migration" (IL8, APOE, and TNF).

\section{Discussion}

The genetics of late-onset $\mathrm{AD}$ is a complex one. More than six-hundred genes have been investigated as susceptibility factors. They represent $2.9 \%$ of all genes with known function (http://www.geneontology.org/). This review focused on fifteen genes that have been consistently associated with LOAD in recent years. Such genes, however, participate in multiple functions, and it is difficult to discriminate which are pathophysiologically meaningful. Gene ontology (GO) is a synoptic way to annotate all functions amenable to a single gene or gene product. We performed a GO analysis of aforementioned genes to identify biological pathways common to all or most of them. In doing so, we discovered that those genes converged onto few pathways that are discussed below.

4.1. Cholesterol Metabolism. Five genes of our compilation (APOE; LDLR; SORL1; CLU; TNF) were implicated in lipid metabolism (four in cholesterol metabolism). This is consistent with epidemiological findings that show how having high cholesterol levels in midlife is a risk factor 
for developing $\mathrm{AD}$ in late life [132]. Beta amyloid is an intrinsically disordered protein (IDP) that lacks a welldefined 3D structure, but it undergoes a series of lipiddependent conformational changes in membrane bilayers. Membrane-bound monomers are transformed into oligomers of varying toxicity rich in beta-sheet structures (annular pores; amyloid fibrils) or in alpha-helix structures (transmembrane channels) [133]. Condensed membrane nano- or microdomains (lipid rafts) formed by sphingolipids and cholesterol are privileged sites for the binding and oligomerisation of amyloidogenic proteins. By controlling the balance between unstructured monomers and $\alpha$ or $\beta$ conformers (the chaperone effect), sphingolipids can either inhibit or stimulate the oligomerisation of amyloidogenic proteins [134]. Cholesterol has a dual role: regulation of protein-sphingolipid interactions through a fine tuning of sphingolipid conformation (indirect effect) and facilitation of pore (or channel) formation through direct binding to amyloidogenic proteins [134]. In view of a key role of cholesterol in beta-amyloid neurotoxicity, statins are currently under evaluation as potentially effective treatment for AD. Recently, a meta-analysis of three randomized trials have yielded negative results [135].

4.2. Vesicle-Mediated Transport/Endocytosis. A secondpathway was endocytosis. This is supported by five genes (PICALM; SORL1; APOE; BIN1; LDLR), and it appears to be involved in APP trafficking. Alterations in the intracellular transport of APP can directly influence whether APP undergoes $\alpha$-secretase enzymatic activity, releasing a nontoxic peptide, $\alpha$-secretase-cleaved soluble APP $(\operatorname{sAPP} \alpha)$, or follows $\beta$-secretase and $\gamma$-secretase enzymatic pathways, leading to generation of the neurotoxic forms of beta amyloid. While the $\alpha$-secretase enzymes are found at the cell surface, $\beta$-secretase lies within the Golgi apparatus and endosomes, the $\gamma$-secretase complex in the endoplasmic reticulum, lysosomes, and the cell surface. When APP is moved into the endosome, it is cleaved by $\beta$-secretase and then transported either to the cell surface or to the lysosome to be further processed by $\gamma$-secretase to form beta amyloid. However, when APP accumulates at the cell surface, it has a greater chance of interacting with $\alpha$-secretase to form nonamyloid-forming sAPP $\alpha[136,137]$.

4.3. Immune System. Seven genes (TNF; IL8; CR1; CLU; CCR2; PICALM; CHRNB2) were found to interfere with the immune system. Neuroinflammation is considered to be a downstream consequence of amyloidogenesis. Betaamyloid deposition within the CNS would bring about the activation of microglia and thus initiate a proinflammatory cascade leading to release potentially neurotoxic substances (cytokines; chemokines; reactive oxygen and nitrogen species; proteolytic enzymes) and to amplify neural damage [138]. It has also been suggested that activated microglia may lead to phosphorylation of tau and formation of neurofibrillary tangles [139, 140]. Based on inflammatory damage, a number of randomized trials compared the efficacy of nonsteroidal anti-inflammatory drugs and COX inhibitors as antidementia treatments but they yielded negative results [141]. Inflammatory cells can also mediate the clearance of beta amyloid via phagocytosis [142, 143]. This has suggested that increased proinflammatory cytokines and activated microglia in $\mathrm{AD}$ patients may be compensatory for defective clearance of beta amyloid on one hand, and this inflammatory cascade may cause brain damage on the other hand [144]. Other pathways emerging from $\mathrm{GO}$ analysis were less frequently discussed. Five genes were implicated in alcohol metabolism. The relationship between alcohol consumption and dementia is dose dependent. Alcohol abuse was associated with increased prevalence of cognitive dysfunction in the elderly, whereas a daily alcohol consumption of less than $40 \mathrm{~g}$ for women and $80 \mathrm{~g}$ for men was protective against cognitive impairment [145]. The protective effect of moderate drinking was confirmed in prospective studies [146]. Instead, heavy drinking usually leads to cognitive disorders, but brain lesions [147] as well as cognitive deficits [148-150] are different in alcohol-related dementia and AD. APOE was found to modulate the link between alcohol and $\mathrm{AD}$ [151]. In particular, the impact of alcohol on brain appears to be more detrimental in APOE epsilon4 carriers [152, 153].

4.4. Genetic Networks. These pathways are actually interconnected. One such network is lipoprotein-inflammation apoptosis. Central links in this chain are APOE and CLU. Animal models have shown the influence of APOE alleles on proinflammatory cytokine (TNF-alpha; IL-6; IL-1) expression and sepsis [154-156]. Recently, we have reported an association between APOE alleles and IL-1beta levels in patients with $\mathrm{AD}$ [157]. Apolipoprotein $\mathrm{E}$ has a protective effect against apoptosis which is significantly reduced in the presence of the pathogenic epsilon 4 isoform [158]. Clusterin that is involved in cholesterol metabolism (it is also named apolipoprotein $\mathrm{J}$ ) and the regulation of complement cascade is known to block apoptosis by binding to proapoptotic mediator Bax and sequestering it in the cytoplasm, thereby, preventing Bax-triggered mitochondrial apoptosis [159]. A second network is centered around intracellular transport of APP, and macroautophagy intracellular transport is mediated by endocytic pathway. Sorting of internalized molecules occurs in the early endosome, which directs the material back to the plasma membrane for recycling, to the transGolgi network for further processing, or to late endosomes and lysosomes for degradation. APP potentially undergoes processing at each of these locations. Early endosomes produce $A \beta$ from APP in normal cells and mediate the uptake of A $\beta$ and soluble APP [160]. Beta-amyloid localization to enlarged endosomes is prominent in early developmental AD $[161,162]$. Macroautophagy is a constitutively active branch of the wider endosome-autophagosome-lysosome system, involved in the sequestration of cytosolic regions into characteristic double-membrane or multimembrane autophagosomes that are delivered to lysosomes for degradation [163]. Macroautophagy interferes with different stages of APP-betaamyloid cycle, and it affects both APP proteolysis to beta amyloid [164] and lysosomal proteolysis in postsecretase APP catabolism [165]. Autophagic vacuole are identifiable by the protein, LC3-II (phospho-lipidated form of microtubuleassociated protein 1 light chain 3-I, MAP1 LC3-I), which 
is associated with both luminal and cytosolic surfaces of vacuole membranes [163]. Classical autophagy activation is regulated through PI3 K/Akt/mTOR pathways although alternative mTOR-independent pathways also exist [166]. The endocytic and autophagy pathways converge onto the lysosom system. Beta amyloid is generated in multivesicular bodies of the endosomal pathway and may also be generated in autophagosomes [167]. In recent years, several genes could be linked to LOAD from large genome-wide association studies (GWASs) [168]. However their effect sizes are small (OR 1.20-1.66), consistent with those reported for other neuropsychiatric disorders [169], and most genetic variability is still unexplained. Using a method similar to the present one, authors clustered functionally interrelated genes, and they tested such networks in ninety-six heritable disorders. This allowed to detect at least one disease gene in $54 \%$ of the loci studied, representing a $2.8 \%$ increase over random selection of candidate genes [170]. This suggests that reconstructing shared functional pathways may significantly reduce the cost and effort of pinpointing true disease genes in disorders for which multiple susceptibility loci have been reported. On the other hand, analyzing complex networks of genes that are altered in AD patients by means of genomics or proteomics, it is possible to dissect them into clusters, each associated with a specific biological pathway. Such clusters could then be investigated in single patients with $\mathrm{AD}$ who are pathophysiologically heterogeneous although they share the same diagnostic label. This would provide more suitable targets for AD treatment.

4.5. Secondary Genetic Effects. Several characteristics of AD patients, not merely diagnostic identification, are affected by $\mathrm{AD}$ genes [86]. These secondary effects should be incorporated to refine genetic networks. A well-known epidemiological finding is that $\mathrm{AD}$ is more prevalent in women $[171,172]$ although authors have contended that this could be an age effect [1]. A connection may exist between gender and APP trafficking. In fact, a few studies have shown that the association of sorting protein genes SORL1 and SORCS1 with LOAD was limited to women $[67,75$, 123]. Similarly, a few haplotypes of LDLR polymorphisms were more represented in $\mathrm{AD}$ patients and associated with altered biomarkers (CSF $\operatorname{Abeta}(42)$; tau protein) in women [98]. Notably, estrogen increases APP transport within the trans-Golgi network [173]. A large subset of patients with AD (60\%-80\%) have neuropsychiatric symptoms such as depression, agitation, and psychosis (behavioral and psychiatric symptoms of dementia, BPSD) [174, 175]. These disturbances are associated with worse prognosis, more rapid cognitive decline, higher costs of care, increased caregiver burden and earlier nursing home placement. Proinflammatory cytokines may play a significant role in BPSD. In fact, the C-511T polymorphism in the promoter region of the IL-1 beta gene was found to correlate with depressive and psychotic symptoms in AD patients $[176,177]$. Similarly, a IL-1alpha SNP (rs1800587) was associated with ADrelated depression [178]. Genetic variations at SORL1 may be associated with AD-related psychosis as well although this is still controversial. In fact, one published study revealed no association between SORL1 polymorphisms and $\mathrm{AD}$ psychosis [179]. On the contrary, we found that SNPs 810 were associated with psychotic manifestations in $\mathrm{AD}$ patients [75]. Among possible endophenotypes, SORL1 was associated with a selective deficit in abstract reasoning [180] and MRI changes [60]. Other genes have been less extensively investigated. CST3 was found to correlate with age of onset in sporadic $\mathrm{AD}$ [181] as well as EEG alterations in subjects with $\mathrm{AD}$ and mild cognitive impairment [182]. Plasma clusterin concentrations were associated with brain atrophy, severity of Alzheimer's disease, and rate of clinical progression although there was no effect of CLU SNPs on gene and protein expression [36].

4.6. Gene-Gene Interactions and Epigenetics. Gene-gene interactions may account for a substantial genetic variability in LOAD. Gene-gene interactions were reported between IL6 and IL10 [183], IL6 and A2M [184], and IL1A and IL8. APOE was found to interact with genes encoding methylenetetrahydrofolate reductase $(M T H F)$ [185], luteinizing hormone receptor [186], and angiotensin-converting enzyme (ACE) [187]. To increase the number of gene-gene interactions, a useful approach could be to investigate genetic networks that are based on homogeneous biological pathways. Epigenetic modifications alter the structure of chromatin to influence gene expression. A common epigenetic pathway is DNA methylation. This occurs naturally on cytosine bases at CpG sequences, and it is usually associated with triggering histone deacetylation, chromatin condensation, and gene silencing. Differentially methylated cytosines give rise to distinct patterns specific for each tissue type and disease state. Among AD genes, PSEN1, APP, and APOE have abundant CpG sites and are significantly affected by methylation [188]. Decrements in markers of DNA methylation were consistently reported in AD neurons and could explain discordant $\mathrm{AD}$ onset in twin pairs [189]. Developmental exposure to xenobiotics such as lead $(\mathrm{Pb})$ influences methylation in $\mathrm{AD}$ genes, and this would predispose to AD later in life [190].

4.7. Pharmacogenomics. Response to antidementia drugs is also affected by genetic factors. Pharmacogenomics in $\mathrm{AD}$ is still in its infancy, with genes associated with $\mathrm{AD}$ pathogenesis and genes responsible for drug metabolism (cytochrome P450) [191]. In monogenic-related studies, APOE-4/4 carriers are the worst responders. In trigenic (APOE-PS1-PS2 clusters)-related studies, the best responders are those patients carrying the 331222-, 341122-, 341222-, and 441112-genomic profiles. The worst responders in all genomic clusters are patients with the $441122+$ genotype. This would indicate a powerful effect of APOE genotypes on therapeutics in networking activity with other ADrelated genes converging on the same biological pathways.

\section{Conclusions}

This review was based on the most comprehensive collection of published studies about the genetics of $\mathrm{AD}$. The best genes were classified according to qualitative criteria such as size of research samples, heterogeneity across studies, and 
control for various sources of bias including small effect size $(\mathrm{OR})$ and publication bias. However, there were also important limitations, mainly due to Alzgene design. First, meta-analyses were restricted to allele contrast, which is less powerful than genotype-based test and allows no inference of the true underlying mode of inheritance, and there was no genetic information at haplotype level. Moreover, only the main effect was investigated, that is diagnostic association with $\mathrm{AD}$, while other clinical phenotypes and endophenotypes could not be considered alongside genegene and gene-environment interactions. On the contrary, a nonnegligible effect of LOAD genes may be directed to these secondary targets as suggested elsewhere. Gene ontologies were developed to provide a shared representation of genes and gene products across species. GO terms contain broad definitions of biological processes in the living cell. Hence, these terms are suitable to identify areas for genomic exploration (e.g., all genes implicated in cholesterol metabolism) but not to elucidate pathogenic mechanisms in depth.

Notwithstanding these caveats including all published studies in a single open-access database (Alzgene) highlights the most important pathophysiological mechanisms, which show the convergence of many genes, and it more easily prompts new biological hypotheses.

\section{References}

[1] Alzheimer's Association, "2010 Alzheimer's disease facts and figures," Alzheimer's and Dementia, vol. 6, no. 2, pp. 158-194, 2010.

[2] G. Binetti, M. S. Mega, E. Magni et al., "Behavioral disorders in Alzheimer disease: a transcultural perspective," Archives of Neurology, vol. 55, no. 4, pp. 539-544, 1998.

[3] M. J. de Leon, A. Convit, S. DeSanti et al., "Neuroimaging and electrophysiology: contribution of structural neuroimaging to the early diagnosis of Alzheimer's disease," International Psychogeriatrics, vol. 9, supplement 1, pp. 183190, 1997.

[4] L. G. Apostolova and P. M. Thompson, "Mapping progressive brain structural changes in early Alzheimer's disease and mild cognitive impairment," Neuropsychologia, vol. 46, no. 6, pp. 1597-1612, 2008.

[5] P. T. Francis, "The interplay of neurotransmitters in Alzheimer's disease," CNS Spectrums, vol. 10, no. 11, pp. 6-9, 2005.

[6] S. Gandy, "The role of cerebral amyloid $\beta$ accumulation in common forms of Alzheimer disease," Journal of Clinical Investigation, vol. 115, no. 5, pp. 1121-1129, 2005.

[7] J. T. Guo, J. Yu, D. Grass, F. C. de Beer, and M. S. Kindy, "Inflammation-dependent cerebral deposition of serum amyloid A protein in a mouse model of amyloidosis," Journal of Neuroscience, vol. 22, no. 14, pp. 5900-5909, 2002.

[8] J. D. Buxbaum, M. Oishi, H. I. Chen et al., "Cholinergic agonists and interleukin 1 regulate processing and secretion of the Alzheimer $\beta / \mathrm{A} 4$ amyloid protein precursor," Proceedings of the National Academy of Sciences of the United States of America, vol. 89, no. 21, pp. 10075-10078, 1992.

[9] I. Blasko, F. Marx, E. Steiner, T. Hartmann, and B. GrubeckLoebenstein, "TNF $\alpha$ plus IFN $\gamma$ induce the production of Alzheimer $\beta$-amyloid peptides and decrease the secretion of APPs," The FASEB Journal, vol. 13, no. 1, pp. 63-68, 1999.
[10] M. Sastre, I. Dewachter, G. E. Landreth et al., "Nonsteroidal anti-inflammatory drugs and peroxisome proliferatoractivated receptor- $\gamma$ agonists modulate immunostimulated processing of amyloid precursor protein through regulation of $\beta$-secretase," Journal of Neuroscience, vol. 23, no. 30, pp. 9796-9804, 2003.

[11] J. W. Lee, Y. K. Lee, D. Y. Yuk et al., "Neuro-inflammation induced by lipopolysaccharide causes cognitive impairment through enhancement of beta-amyloid generation," Journal of Neuroinflammation, vol. 5, article no. 37, 2008.

[12] D. Gate, K. Rezai-Zadeh, D. Jodry, A. Rentsendorj, and T. Town, "Macrophages in Alzheimer's disease: the blood-borne identity," Journal of Neural Transmission, vol. 117, no. 8, pp. 961-970, 2010.

[13] B. De Strooper and W. Annaert, "Proteolytic processing and cell biological functions of the amyloid precursor protein," Journal of Cell Science, vol. 113, no. 11, pp. 1857-1870, 2000.

[14] A. Lorenzen, J. Samosh, K. Vandewark et al., "Rapid and direct transport of cell surface APP to the lysosome defines a novel selective pathway," Molecular Brain, vol. 3, no. 1, article $11,2010$.

[15] O. M. Andersen, J. Reiche, V. Schmidt et al., "Neuronal sorting protein-related receptor sorLA/LR11 regulates processing of the amyloid precursor protein," Proceedings of the National Academy of Sciences of the United States of America, vol. 102, no. 38, pp. 13461-13466, 2005.

[16] K. Offe, S. E. Dodson, J. T. Shoemaker et al., "The lipoprotein receptor LR11 regulates amyloid $\beta$ production and amyloid precursor protein traffic in endosomal compartments," Journal of Neuroscience, vol. 26, no. 5, pp. 1596-1603, 2006.

[17] T. Jaworski, S. Kügler, and F. Van Leuven, "Modeling of Taumediated synaptic and neuronal degeneration in Alzheimer's disease," International Journal of Alzheimer's Disease, vol. 2010, Article ID 573138, 10 pages, 2010.

[18] K. Iqbal, F. Liu, C. X. Gong, and I. Grundke-Iqbal, "Tau in Alzheimer disease and related Tauopathies," Current Alzheimer Research, vol. 7, pp. 656-664, 2010.

[19] J. C. Breitner, “APOE genotyping and Alzheimer's disease.," The Lancet, vol. 347, no. 9009, pp. 1184-1185, 1996.

[20] C. Talbot, C. Lendon, N. Craddock, S. Shears, J. C. Morris, and A. Goate, "Protection against Alzheimer's disease with apoE ع2," The Lancet, vol. 343, no. 8910, pp. 1432-1433, 1994.

[21] E. H. Corder, A. M. Saunders, N. J. Risch et al., "Protective effect of apolipoprotein $\mathrm{E}$ type 2 allele for late onset Alzheimer disease," Nature Genetics, vol. 7, no. 2, pp. 180184, 1994.

[22] L. Bertram, M. B. McQueen, K. Mullin, D. Blacker, and R. E. Tanzi, "Systematic meta-analyses of Alzheimer disease genetic association studies: the AlzGene database," Nature Genetics, vol. 39, no. 1, pp. 17-23, 2007.

[23] R. DerSimonian and N. Laird, "Meta-analysis in clinical trials," Controlled Clinical Trials, vol. 7, no. 3, pp. 177-188, 1986.

[24] J. P. A. Ioannidis, P. Boffetta, J. Little et al., "Assessment of cumulative evidence on genetic associations: interim guidelines," International Journal of Epidemiology, vol. 37, no. 1, pp. 120-132, 2008.

[25] S. Carbon, A. Ireland, C. J. Mungall et al., "AmiGO: online access to ontology and annotation data," Bioinformatics, vol. 25, no. 2, pp. 288-289, 2009.

[26] E. Kida, N. H. Choi-Miura, and K. E. Wisniewski, "Deposition of apolipoproteins $\mathrm{E}$ and $\mathrm{J}$ in senile plaques is topographically determined in both Alzheimer's disease and 
Down's syndrome brain," Brain Research, vol. 685, no. 1-2, pp. 211-216, 1995.

[27] R. D. Bell, A. P. Sagare, A. E. Friedman et al., "Transport pathways for clearance of human Alzheimer's amyloid $\beta$-peptide and apolipoproteins $\mathrm{E}$ and $\mathrm{J}$ in the mouse central nervous system," Journal of Cerebral Blood Flow and Metabolism, vol. 27, no. 5, pp. 909-918, 2007.

[28] J. C. Lambert, S. Heath, G. Even et al., "Genome-wide association study identifies variants at CLU and CR1 associated with Alzheimer's disease," Nature Genetics, vol. 41, no. 10, pp. 1094-1099, 2009.

[29] D. Harold, R. Abraham, P. Hollingworth et al., "Genomewide association study identifies variants at CLU and PICALM associated with Alzheimer's disease," Nature Genetics, vol. 41, no. 10, pp. 1088-1093, 2009.

[30] S. Seshadri, A. L. Fitzpatrick, M. A. Ikram et al., "Genomewide analysis of genetic loci associated with Alzheimer disease," Journal of the American Medical Association, vol. 303, no. 18, pp. 1832-1840, 2010.

[31] J. J. Corneveaux, A. J. Myers, A. N. Allen et al., "Association of CR1, CLU and PICALM with Alzheimer's disease in a cohort of clinically characterized and neuropathologically verified individuals," Human Molecular Genetics, vol. 19, no. 16, Article ID ddq221, pp. 3295-3301, 2010.

[32] V. Giedraitis, L. Kilander, M. Degerman-Gunnarsson et al., "Genetic analysis of Alzheimer's disease in the Uppsala Longitudinal Study of Adult Men," Dementia and Geriatric Cognitive Disorders, vol. 27, no. 1, pp. 59-68, 2009.

[33] M. M. Carrasquillo, O. Belbin, T. A. Hunter et al., "Replication of CLU, CR1, and PICALM associations with Alzheimer disease," Archives of Neurology, vol. 67, no. 8, pp. 961-964, 2010.

[34] R. J. Guerreiro, J. Beck, J. R. Gibbs et al., "Genetic variability in CLU and its association with Alzheimer's disease," PLoS ONE, vol. 5, no. 3, Article ID e9510, 2010.

[35] T. Nuutinen, T. Suuronen, A. Kauppinen, and A. Salminen, "Valproic acid stimulates clusterin expression in human astrocytes: implications for Alzheimer's disease," Neuroscience Letters, vol. 475, no. 2, pp. 64-68, 2010.

[36] M. Thambisetty, A. Simmons, L. Velayudhan et al., "Association of plasma clusterin concentration with severity, pathology, and progression in Alzheimer disease," Archives of General Psychiatry, vol. 67, no. 7, pp. 739-748, 2010.

[37] L. M. Traub, "Common principles in clathrin-mediated sorting at the Golgi and the plasma membrane," Biochimica et Biophysica Acta, vol. 1744, no. 3, pp. 415-437, 2005.

[38] A. Harel, F. Wu, M. P. Mattson, C. M. Morris, and P. J. Yao, "Evidence for CALM in Directing VAMP2 Trafficking," Traffic, vol. 9, no. 3, pp. 417-429, 2008.

[39] E. Masliah, M. Mallory, M. Alford et al., "Altered expression of synaptic proteins occurs early during progression of Alzheimer's disease," Neurology, vol. 56, no. 1, pp. 127-129, 2001.

[40] J. R. Cirrito, J. E. Kang, J. Lee et al., "Endocytosis is required for synaptic activity-dependent release of amyloid- $\beta$ in vivo," Neuron, vol. 58, no. 1, pp. 42-51, 2008.

[41] A. Biffi, C. D. Anderson, R. S. Desikan et al., "Genetic variation and neuroimaging measures in Alzheimer disease," Archives of Neurology, vol. 67, no. 6, pp. 677-685, 2010.

[42] M. I. Kamboh, R. L. Minster, F. Y. Demirci et al., "Association of $C L U$ and PICALM variants with Alzheimer's disease," Neurobiology of Aging. In Press.

[43] I. E. Vega and S. C. Hsu, "The Exocyst complex associates with microtubules to mediate vesicle targeting and neurite outgrowth," Journal of Neuroscience, vol. 21, no. 11, pp. 38393848, 2001.

[44] S. Pant, M. Sharma, K. Patel, S. Caplan, C. M. Carr, and B. D. Grant, "AMPH-1/Amphiphysin/Bin1 functions with RME1/Ehd1 in endocytic recycling," Nature Cell Biology, vol. 11, no. 12, pp. 1399-1410, 2009.

[45] G. Ren, P. Vajjhala, J. S. Lee, B. Winsor, and A. L. Munn, "The BAR domain proteins: molding membranes in fission, fusion, and phagy," Microbiology and Molecular Biology Reviews, vol. 70, no. 1, pp. 37-120, 2006.

[46] U. Galderisi, G. Di Bernardo, M. Cipollaro et al., "Induction of apoptosis and differentiation in neuroblastoma and astrocytoma cells by the overexpression of Bin1, a novel Myc interacting protein," Journal of Cellular Biochemistry, vol. 74, no. 3, pp. 313-322, 1999.

[47] M. D. Hogarty, X. Liu, P. M. Thompson et al., "BIN1 inhibits colony formation and induces apoptosis in neuroblastoma cell lines with MYCN amplification," Medical and Pediatric Oncology, vol. 35, no. 6, pp. 559-562, 2000.

[48] K. Elliott, K. Ge, W. Du, and G. C. Prendergast, "The cMyc-interacting adaptor protein Bin1 activates a caspaseindependent cell death program," Oncogene, vol. 19, no. 41, pp. 4669-4684, 2000.

[49] M. Krych-Goldberg and J. P. Atkinson, "Structure-function relationships of complement receptor type 1," Immunological Reviews, vol. 180, pp. 112-122, 2001.

[50] T. Wyss-Coray, F. Yan, A. H. T. Lin et al., "Prominent neurodegeneration and increased plaque formation in complement-inhibited Alzheimer's mice," Proceedings of the National Academy of Sciences of the United States of America, vol. 99, no. 16, pp. 10837-10842, 2002.

[51] J. Rogers, R. Li, D. Mastroeni et al., "Peripheral clearance of amyloid $\beta$ peptide by complement C3-dependent adherence to erythrocytes," Neurobiology of Aging, vol. 27, no. 12, pp. 1733-1739, 2006.

[52] E. M. Reiman, J. A. Webster, A. J. Myers et al., "GAB2 alleles modify Alzheimer's risk in APOE $\varepsilon 4$ carriers," Neuron, vol. 54, no. 5, pp. 713-720, 2007.

[53] G. Thinakaran and E. H. Koo, "Amyloid precursor protein trafficking, processing, and function," Journal of Biological Chemistry, vol. 283, no. 44, pp. 29615-29619, 2008.

[54] J. H. Lee, M. Chulikavit, D. Pang, W. B. Zigman, W. Silverman, and N. Schupf, "Association between genetic variants in sortilin-related receptor 1 (SORL1) and Alzheimer's disease in adults with Down syndrome," Neuroscience Letters, vol. 425, no. 2, pp. 105-109, 2007.

[55] J. H. Lee, R. Cheng, N. Schupf et al., "The association between genetic variants in SORL1 and Alzheimer disease in an urban, multiethnic, community-based cohort," Archives of Neurology, vol. 64, no. 4, pp. 501-506, 2007.

[56] F. Liu, A. Arias-Vásquez, K. Sleegers et al., "A genomewide screen for late-onset Alzheimer disease in a genetically isolated Dutch population," The American Journal of Human Genetics, vol. 81, no. 1, pp. 17-31, 2007.

[57] Y. Meng, J. H. Lee, R. Cheng, P. St George-Hyslop, R. Mayeux, and L. A. Farrer, "Association between SORL1 and Alzheimer's disease in a genome-wide study," NeuroReport, vol. 18, no. 17, pp. 1761-1764, 2007.

[58] E. Rogaeva, Y. Meng, J. H. Lee et al., "The neuronal sortilin-related receptor SORL1 is genetically associated with Alzheimer disease," Nature Genetics, vol. 39, no. 2, pp. 168$177,2007$.

[59] K. Bettens, N. Brouwers, S. Engelborghs, P. P. De Deyn, C. Van Broeckhoven, and K. Sleegers, "SORL1 is genetically 
associated with increased risk for late-onset Alzheimer disease in the Belgian population," Human Mutation, vol. 29, no. 5, pp. 769-770, 2008.

[60] K. T. Cuenco, K. L. Lunetta, C. T. Baldwin et al., "Association of distinct variants in SORL1 with cerebrovascular and neurodegenerative changes related to Alzheimer disease," Archives of Neurology, vol. 65, no. 12, pp. 1640-1648, 2008.

[61] J. H. Lee, N. Shibata, R. Cheng, and R. Mayeux, "Possible association between SORL1 and Alzheimer disease? Reanalysing the data of Shibata et al," Dementia and Geriatric Cognitive Disorders, vol. 26, no. 5, p. 482, 2008.

[62] J. H. Lee, S. Barral, and C. Reitz, "The neuronal sortilinrelated receptor gene SORL1 and late-onset Alzheimer's disease," Current Neurology and Neuroscience Reports, vol. 8, no. 5, pp. 384-391, 2008.

[63] J. H. Lee, R. Cheng, L. S. Honig, J. P. G. Vonsattel, L. Clark, and R. Mayeux, "Association between genetic variants in SORL1 and autopsy-confirmed Alzheimer disease," Neurology, vol. 70, no. 11, pp. 887-889, 2008.

[64] Y. Li, C. Rowland, J. Catanese et al., "SORL1 variants and risk of late-onset Alzheimer's disease," Neurobiology of Disease, vol. 29, no. 2, pp. 293-296, 2008.

[65] R. L. Minster, S. T. DeKosky, and M. I. Kamboh, "No association of SORL1 SNPs with Alzheimer's disease," Neuroscience Letters, vol. 440, no. 2, pp. 190-192, 2008.

[66] J. A. Webster, A. J. Myers, J. V. Pearson et al., "Sorl1 as an Alzheimer's disease predisposition gene?" Neurodegenerative Diseases, vol. 5, no. 2, pp. 60-64, 2008.

[67] E. Cellini, A. Tedde, S. Bagnoli et al., "Implication of sex and SORL1 variants in Italian patients with Alzheimer disease," Archives of Neurology, vol. 66, no. 10, pp. 1260-1266, 2009.

[68] R. Kimura, M. Yamamoto, T. Morihara et al., "SORL1 is genetically associated with Alzheimer disease in a Japanese population," Neuroscience Letters, vol. 461, no. 2, pp. 177180, 2009.

[69] H. Kölsch, F. Jessen, J. Wiltfang et al., "Association of SORL1 gene variants with Alzheimer's disease," Brain Research, vol. 1264, pp. 1-6, 2009.

[70] F. Liu, M. A. Ikram, A. C. J. W. Janssens et al., "A study of the SORL1 Gene in Alzheimer's disease and cognitive function," Journal of Alzheimer's Disease, vol. 18, no. 1, pp. 51-64, 2009.

[71] C. A. Reynolds, M. G. Hong, U. K. Eriksson et al., "Sequence variation in SORL1 and dementia risk in Swedes," Neurogenetics, vol. 11, no. 1, pp. 139-142, 2010.

[72] B. M. M. Schjeide, M. B. McQueen, K. Mullin et al., "Assessment of Alzheimer's disease case-control associations using family-based methods," Neurogenetics, vol. 10, no. 1, pp. 19-25, 2009.

[73] E. K. Tan, J. Lee, C. P. Chen, Y. Y. Teo, Y. Zhao, and W. L. Lee, "SORL1 haplotypes modulate risk of Alzheimer's disease in Chinese," Neurobiology of Aging, vol. 30, no. 7, pp. 10481051, 2009.

[74] G. Laumet, V. Chouraki, B. Grenier-Boley et al., "Systematic analysis of candidate genes for Alzheimer's disease in a French, genome-wide association study," Journal of Alzheimer's Disease, vol. 20, no. 4, pp. 1181-1188, 2010.

[75] P. Olgiati, A. Politis, and D. Albani, "Effects of SORL1 gene on Alzheimer's disease: focus on gender, neuropsychiatric symptoms and pro-inflammatory cytokines," Current Alzheimer Research. In Press.

[76] N. Azoitei, A. Brey, T. Busch, S. Fulda, G. Adler, and T. Seufferlein, "Thirty-eight-negative kinase 1 (TNK1) facilitates $\mathrm{TNF} \alpha$-induced apoptosis by blocking NF- $\kappa \mathrm{B}$ activation," Oncogene, vol. 26, no. 45, pp. 6536-6545, 2007.
[77] A. Grupe, R. Abraham, Y. Li et al., "Evidence for novel susceptibility genes for late-onset Alzheimer's disease from a genome-wide association study of putative functional variants," Human Molecular Genetics, vol. 16, no. 8, pp. 865873, 2007.

[78] D. Galimberti, N. Schoonenboom, P. Scheltens et al., "Intrathecal chemokine synthesis in mild cognitive impairment and Alzheimer disease," Archives of Neurology, vol. 63, no. 4, pp. 538-543, 2006.

[79] L. Meda, C. Bonaiuto, G. I. Szendrei, M. Ceska, F. Rossi, and M. A. Cassatella, " $\beta$-Amyloid(25-35) induces the production of interleukin-8 from human monocytes," Journal of Neuroimmunology, vol. 59, no. 1-2, pp. 29-33, 1995.

[80] J. Infante, C. Sanz, J. L. Fernández-Luna, J. Llorca, J. Berciano, and O. Combarros, "Gene-gene interaction between interleukin-1A and interleukin-8 increases Alzheimer's disease risk," Journal of Neurology, vol. 251, no. 4, pp. 482-483, 2004.

[81] A. A. Vendramini, R. W. de Lábio, L. T. Rasmussen et al., "Interleukin-8 gene polymorphism -251T $>\mathrm{A}$ and Alzheimer's disease," Journal of Alzheimer's Disease, vol. 12, no. 3, pp. 221-222, 2007.

[82] K. Li, S. Liu, S. Yao, B. Wang, D. Dai, and L. Yao, "Interaction between interleukin-8 and methylenetetrahydrofolate reductase genes modulates Alzheimer's disease risk," Dementia and Geriatric Cognitive Disorders, vol. 27, no. 3, pp. 286-291, 2009.

[83] D. H. Linkous, P. A. Adlard, P. B. Wanschura, K. M. Conko, and J. M. Flinn, "The effects of enhanced zinc on spatial memory and plaque formation in transgenic mice," Journal of Alzheimer's Disease, vol. 18, no. 3, pp. 565-579, 2009.

[84] Y. Miller, B. Ma, and R. Nussinov, "Zinc ions promote Alzheimer a $\beta$ aggregation via population shift of polymorphic states," Proceedings of the National Academy of Sciences of the United States of America, vol. 107, no. 21, pp. 9490-9495, 2010.

[85] E. Mariani, L. Cattini, S. Neri et al., "Simultaneous evaluation of circulating chemokine and cytokine profiles in elderly subjects by multiplex technology: relationship with zinc status," Biogerontology, vol. 7, no. 5-6, pp. 449-459, 2006.

[86] A. Serretti, P. Olgiati, and D. De Ronchi, "Genetics of Alzheimer's disease: a rapidly evolving field," Journal of Alzheimer's Disease, vol. 12, no. 1, pp. 73-92, 2007.

[87] B. Bao, A. S. Prasad, F. W.J. Beck, and M. Godmere, "Zinc modulates mRNA levels of cytokines," American Journal of Physiology, vol. 285, pp. E1095-E1102, 2003.

[88] J. Kim, J. M. Castellano, H. Jiang et al., "Overexpression of low-density lipoprotein receptor in the brain markedly inhibits amyloid deposition and increases extracellular $\mathrm{A} \beta$ clearance," Neuron, vol. 64, no. 5, pp. 632-644, 2009.

[89] G. Bu, J. Cam, and C. Zerbinatti, "LRP in amyloid- $\beta$ production and metabolism," Annals of the New York Academy of Sciences, vol. 1086, pp. 35-53, 2006.

[90] C. L. Lendon, C. J. Talbot, N. J. Craddock et al., "Genetic association studies between dementia of the Alzheimer's type and three receptors for apolipoprotein $\mathrm{E}$ in a Caucasian population," Neuroscience Letters, vol. 222, no. 3, pp. 187190, 1997.

[91] W. Retz, J. Thome, N. Durany et al., "Potential genetic markers of sporadic Alzheimer's dementia," Psychiatric Genetics, vol. 11, no. 3, pp. 115-122, 2001.

[92] R. Scacchi, G. Gambina, M. C. Martini et al., "Polymorphisms of the apolipoprotein E gene regulatory region and of the LDL receptor gene in late-onset Alzheimer's disease 
in relation to the plasma lipidic pattern," Dementia and Geriatric Cognitive Disorders, vol. 12, no. 2, pp. 63-68, 2001.

[93] A. Papassotiropoulos, M. A. Wollmer, M. Tsolaki et al., "A cluster of cholesterol-related genes confers susceptibility for Alzheimer's disease," Journal of Clinical Psychiatry, vol. 66, no. 7, pp. 940-947, 2005.

[94] D. Cheng, R. Huang, I. S. Lanham et al., "Functional interaction between APOE4 and LDL receptor isoforms in Alzheimer's disease," Journal of Medical Genetics, vol. 42, no. 2, pp. 129-131, 2005.

[95] R. K. Gopalraj, H. Zhu, J. F. Kelly et al., "Genetic association of low density lipoprotein receptor and Alzheimer's disease," Neurobiology of Aging, vol. 26, no. 1, pp. 1-7, 2005.

[96] E. H. Corder, R. Huang, H. M. Cathcart et al., "Membership in genetic groups predicts Alzheimer disease," Rejuvenation Research, vol. 9, no. 1, pp. 89-93, 2006.

[97] E. Rodríguez, I. Mateo, J. Llorca et al., "No association between low density lipoprotein receptor genetic variants and Alzheimer's disease risk," American Journal of Medical Genetics B, vol. 141, no. 5, pp. 541-543, 2006.

[98] R. Lämsä, S. Helisalmi, S.-K. Herukka et al., "Genetic study evaluating LDLR polymorphisms and Alzheimer's disease," Neurobiology of Aging, vol. 29, no. 6, pp. 848-855, 2008.

[99] F. Zou, R. K. Gopalraj, J. Lok et al., "Sex-dependent association of a common low-density lipoprotein receptor polymorphism with RNA splicing efficiency in the brain and Alzheimer's disease," Human Molecular Genetics, vol. 17, no. 7, pp. 929-935, 2008.

[100] W. Mi, M. Pawlik, M. Sastre et al., "Cystatin C inhibits amyloid- $\beta$ deposition in Alzheimer's disease mouse models," Nature Genetics, vol. 39, no. 12, pp. 1440-1442, 2007.

[101] J. Sundelöf, J. Sundström, O. Hansson et al., "Cystatin C levels are positively correlated with both $\mathrm{A} \beta 42$ and tau levels in cerebrospinal fluid in persons with Alzheimer's disease, mild cognitive impairment, and healthy controls," Journal of Alzheimer's Disease, vol. 21, no. 2, pp. 471-478, 2010.

[102] U. Finckh, H. von der Kammer, J. Velden et al., "Genetic association of a cystatin $\mathrm{C}$ gene polymorphism with lateonset Alzheimer disease," Archives of Neurology, vol. 57, no. 11, pp. 1579-1583, 2000.

[103] F. C. Crawford, M. J. Freeman, J. A. Schinka et al., "A polymorphism in the cystatin $\mathrm{C}$ gene is a novel risk factor for late-onset Alzheimer's disease," Neurology, vol. 55, no. 6, pp. 763-768, 2000.

[104] K. Beyer, J. I. Lao, M. Gómez et al., "Alzheimer's disease and the cystatin C gene polymorphism: an association study," Neuroscience Letters, vol. 315, no. 1-2, pp. 17-20, 2001.

[105] R. C. Dodel, Y. Du, C. Depboylu et al., "A polymorphism in the cystatin $\mathrm{C}$ promoter region is not associated with an increased risk of AD," Neurology, vol. 58, no. 4, p. 664, 2002.

[106] K. A. B. Goddard, J. M. Olson, H. Payami, M. van der Voet, H. Kuivaniemi, and G. Tromp, "Evidence of linkage and association on chromosome 20 for late-onset Alzheimer disease," Neurogenetics, vol. 5, no. 2, pp. 121-128, 2004.

[107] B. Nacmias, S. Bagnoli, A. Tedde et al., "Cystatin C and apoe polymorphisms in Italian Alzheimer's disease," Neuroscience Letters, vol. 392, no. 1-2, pp. 110-113, 2006.

[108] R. Monastero, C. Camarda, A. B. Cefalù et al., "No association between the cystatin $\mathrm{C}$ gene polymorphism and Alzheimer's disease: a case-control study in an Italian population," Journal of Alzheimer's Disease, vol. 7, no. 4, pp. 291-295, 2005.

[109] C. N. Randall, D. Strasburger, J. Prozonic et al., "Cluster analysis of risk factor genetic polymorphisms in Alzheimer's disease," Neurochemical Research, vol. 34, no. 1, pp. 23-28, 2009.

[110] H. M. Cathcart, R. Huang, I. S. Lanham, E. H. Corder, and S. E. Poduslo, "Cystatin $\mathrm{C}$ as a risk factor for Alzheimer disease," Neurology, vol. 64, no. 4, pp. 755-757, 2005.

[111] S. Helisalmi, A. Väkevä, M. Hiltunen, and H. Soininen, "Flanking markers of cystatin C (CST3) gene do not show association with Alzheimer's disease," Dementia and Geriatric Cognitive Disorders, vol. 27, no. 4, pp. 318-321, 2009.

[112] B. Wang, Y. C. Xie, Z. Yang et al., "Lack of an association between Alzheimer's disease and the cystatin C (CST3) gene G73A polymorphism in mainland Chinese," Dementia and Geriatric Cognitive Disorders, vol. 25, no. 5, pp. 461-464, 2008.

[113] L. J. Chuo, W. H. H. Sheu, M. C. Pai, and Y. M. Kuo, "Genotype and plasma concentration of cystatin C in patients with late-onset Alzheimer disease," Dementia and Geriatric Cognitive Disorders, vol. 23, no. 4, pp. 251-257, 2007.

[114] C. Lin, S. T. Wang, C. W. Wu, L. J. Chuo, and Y. M. Kuo, “The association of a cystatin $\mathrm{C}$ gene polymorphism with lateonset Alzheimer's disease and vascular dementia," Chinese Journal of Physiology, vol. 46, no. 3, pp. 111-115, 2003.

[115] H. Maruyama, Y. Izumi, M. Oda et al., "Lack of an association between cystatin C gene polymorphisms in Japanese patients with Alzheimer's disease," Neurology, vol. 57, no. 2, pp. 337339, 2001.

[116] J. Kawamata and S. Shimohama, "Association of novel and established polymorphisms in neuronal nicotinic acetylcholine receptors with sporadic Alzheimer's disease," Journal of Alzheimer's Disease, vol. 4, no. 2, pp. 71-76, 2002.

[117] L. J. Cook, L. W. Ho, A. E. Taylor et al., "Candidate gene association studies of the $\alpha 4$ (CHRNA4) and $\beta 2$ (CHRNB2) neuronal nicotinic acetylcholine receptor subunit genes in Alzheimer's disease," Neuroscience Letters, vol. 358, no. 2, pp. 142-146, 2004.

[118] T. M. Feulner, S. M. Laws, P. Friedrich et al., "Examination of the current top candidate genes for $\mathrm{AD}$ in a genome-wide association study," Molecular Psychiatry, vol. 15, no. 7, pp. 756-766, 2009.

[119] H. Li, S. Wetten, L. Li et al., "Candidate single-nucleotide polymorphisms from a genomewide association study of Alzheimer disease," Archives of Neurology, vol. 65, no. 1, pp. 45-53, 2008.

[120] P. Podlesniy, A. Kichev, C. Pedraza et al., "Pro-NGF from Alzheimer's disease and normal human brain displays distinctive abilities to induce processing and nuclear translocation of intracellular domain of p75NTR and apoptosis," American Journal of Pathology, vol. 169, no. 1, pp. 119-131, 2006.

[121] R. F. Lane, S. M. Raines, J. W. Steele et al., "Diabetesassociated SorCS1 regulates Alzheimer's amyloid- $\beta$ metabolism: evidence for involvement of SorL1 and the retromer complex," Journal of Neuroscience, vol. 30, no. 39, pp. 13110 13115, 2010.

[122] C. Granhall, H. B. Park, H. Fakhrai-Rad, and H. Luthman, "High-resolution quantitative trait locus analysis reveals multiple diabetes susceptibility loci mapped to intervals $<800 \mathrm{~kb}$ in the species-conserved Niddmli of the GK rat," Genetics, vol. 174, no. 3, pp. 1565-1572, 2006.

[123] X. Liang, M. Slifer, E. R. Martin et al., "Genomic convergence to identify candidate genes for Alzheimer disease on chromosome 10," Human Mutation, vol. 30, no. 3, pp. 463-471, 2009.

[124] Z. S. Tan, A. S. Beiser, R. S. Vasan et al., "Inflammatory markers and the risk of Alzheimer disease: the Framingham study," Neurology, vol. 68, no. 22, pp. 1902-1908, 2007. 
[125] S. L. Ma, N. L. S. Tang, L. C. W. Lam, and H. F. K. Chiu, "Association between tumor necrosis factor- $\alpha$ promoter polymorphism and Alzheimer's disease," Neurology, vol. 62, no. 2, pp. 307-309, 2004.

[126] M. Nishimura, T. Sakamoto, R. Kaji, and H. Kawakami, "Influence of polymorphisms in the genes for cytokines and glutathione S-transferase omega on sporadic Alzheimer's disease," Neuroscience Letters, vol. 368, no. 2, pp. 140-143, 2004.

[127] H. C. Fung, C. M. Chen, Y. R. Wu et al., "Heat shock protein 70 and tumor necrosis factor alpha in Taiwanese patients with dementia," Dementia and Geriatric Cognitive Disorders, vol. 20 , no. 1, pp. 1-7, 2005.

[128] C. Holmes, C. Cunningham, E. Zotova et al., "Systemic inflammation and disease progression in Alzheimer disease," Neurology, vol. 73, no. 10, pp. 768-774, 2009.

[129] E. L. Tobinick and H. Gross, "Rapid improvement in verbal fluency and aphasia following perispinal etanercept in Alzheimer's disease," BMC Neurology, vol. 8, article 27, 2008.

[130] D. Galimberti, C. Fenoglio, C. Lovati et al., "CCR2-64I polymorphism and CCR $5 \Delta 32$ deletion in patients with Alzheimer's disease," Journal of the Neurological Sciences, vol. 225, no. 1-2, pp. 79-83, 2004.

[131] C. Huerta, V. Álvarez, I. F. Mata et al., "Chemokines (RANTES and MCP-1) and chemokine-receptors (CCR2 and CCR5) gene polymorphisms in Alzheimer's and Parkinson's disease," Neuroscience Letters, vol. 370, no. 2-3, pp. 151-154, 2004.

[132] A. Solomon, M. Kivipelto, B. Wolozin, J. Zhou, and R. A. Whitmer, "Midlife serum cholesterol and increased risk of Alzheimer's and vascular dementia three decades later," Dementia and Geriatric Cognitive Disorders, vol. 28, no. 1, pp. 75-80, 2009.

[133] B. L. Kagan and J. Thundimadathil, "Amyloid peptide pores and the beta sheet conformation," Advances in Experimental Medicine and Biology, vol. 677, pp. 150-167, 2010.

[134] J. Fantini and N. Yahi, "Molecular insights into amyloid regulation by membrane cholesterol and sphingolipids: common mechanisms in neurodegenerative diseases," Expert Reviews in Molecular Medicine, vol. 12, p. e27, 2010.

[135] B. McGuinness and P. Passmore, "Can statins prevent or help treat Alzheimer's disease?" Journal of Alzheimer's Disease, vol. 20, no. 3, pp. 925-933, 2010.

[136] R. Mayeux and P. S. G. Hyslop, “Alzheimer's disease: advances in trafficking," The Lancet Neurology, vol. 7, no. 1, pp. 2-3, 2008.

[137] R. Mayeux and P. St George-Hyslop, "Brain traffic: subcellular transport of the amyloid precursor protein," Archives of Neurology, vol. 66, no. 4, pp. 433-434, 2009.

[138] J. Rogers, "The inflammatory response in Alzheimer's disease," Journal of Periodontology, vol. 79, no. 8, pp. 1535-1543, 2008.

[139] R. A. Quintanilla, D. I. Orellana, C. González-Billault, and R. B. Maccioni, "Interleukin-6 induces Alzheimer-type phosphorylation of tau protein by deregulating the cdk5/p35 pathway," Experimental Cell Research, vol. 295, no. 1, pp. 245257, 2004.

[140] I. Morales, G. Farías, and R. B. Maccioni, "Neuroimmunomodulation in the pathogenesis of Alzheimer's disease," NeuroImmunomodulation, vol. 17, no. 3, pp. 202-204, 2010.

[141] B. P. Imbimbo, "An update on the efficacy of non-steroidal anti-inflammatory drugs in Alzheimer's disease," Expert Opinion on Investigational Drugs, vol. 18, no. 8, pp. 1147$1168,2009$.
[142] R. B. Weltzien and J. S. Pachter, "Visualization of betaamyloid peptide $(A \beta)$ phagocytosis by human mononuclear phagocytes: dependency on A $\beta$ aggregate size," Journal of Neuroscience Research, vol. 59, no. 4, pp. 522-527, 2000.

[143] D. Morgan, "The role of microglia in antibody-mediated clearance of amyloid-beta from the brain," CNS and Neurological Disorders—Drug Targets, vol. 8, no. 1, pp. 7-15, 2009.

[144] M. Fiala, D. H. Cribbs, M. Rosenthal, and G. Bernard, "Phagocytosis of amyloid- $\beta$ and inflammation: two faces of innate immunity in Alzheimer's disease," Journal of Alzheimer's Disease, vol. 11, no. 4, pp. 457-463, 2007.

[145] G. Zuccalà, G. Onder, C. Pedone et al., "Dose-related impact of alcohol consumption on cognitive function in advanced age: results of a multicenter survey," Alcoholism: Clinical and Experimental Research, vol. 25, no. 12, pp. 1743-1748, 2001.

[146] K. J. Anstey, H. A. Mack, and N. Cherbuin, "Alcohol consumption as a risk factor for dementia and cognitive decline: meta-analysis of prospective studies," American Journal of Geriatric Psychiatry, vol. 17, no. 7, pp. 542-555, 2009.

[147] L. Aho, K. Karkola, J. Juusela, and I. Alafuzoff, "Heavy alcohol consumption and neuropathological lesions: a post-mortem human study," Journal of Neuroscience Research, vol. 87, no. 12, pp. 2786-2792, 2009.

[148] J. Saxton, C. A. Munro, M. A. Butters, C. Schramke, and M. A. McNeil, "Alcohol, dementia, and Alzheimer's disease: comparison of neuropsychological profiles," Journal of Geriatric Psychiatry and Neurology, vol. 13, no. 3, pp. 141149, 2000.

[149] K. S. Schmidt, J. L. Gallo, C. Ferri et al., "The neuropsychological profile of alcohol-related dementia suggests cortical and subcortical pathology," Dementia and Geriatric Cognitive Disorders, vol. 20, no. 5, pp. 286-291, 2005.

[150] I. Liappas, I. Theotoka, E. Kapaki, I. Ilias, G. P. Paraskevas, and C. R. Soldatos, "Neuropsychological assessment of cognitive function in chronic alcohol-dependent patients and patients with Alzheimer's disease," In Vivo, vol. 21, no. 6, pp. 1115-1118, 2007.

[151] M. Kivipelto, S. Rovio, T. Ngandu et al., "Apolipoprotein E epsilon4 magnifies lifestyle risks for dementia: a populationbased study," Journal of Cellular and Molecular Medicine, vol. 12, pp. 2762-2771, 2008.

[152] T. De Heijer, S. E. Vermeer, E. J. van Dijk et al., "Alcohol intake in relation to brain magnetic resonance imaging findings in older persons without dementia," The American Journal of Clinical Nutrition, vol. 80, no. 4, pp. 992-997, 2004.

[153] M. S. Mega, J. L. Cummings, T. Fiorello, and J. Gornbein, "The spectrum of behavioral changes in Alzheimer's disease," Neurology, vol. 46, pp. 130-135, 1996.

[154] M. P. Vitek, C. M. Brown, and C. A. Colton, "APOE genotype-specific differences in the innate immune response," Neurobiology of Aging, vol. 30, no. 9, pp. 1350-1360, 2009.

[155] H. Wang, D. J. Christensen, M. P. Vitek, P. M. Sulivan, and D. T. Laskowitz, "APOE genotype affects outcome in a murine model of sepsis: implications for a new treatment strategy," Anaesthesia and Intensive Care, vol. 37, no. 1, pp. 38-45, 2009.

[156] M. Yin, L. Zhang, X. M. Sun, L. F. Mao, and J. Pan, "Lack of apoE causes alteration of cytokines expression in young mice liver," Molecular Biology Reports, vol. 37, no. 4, pp. 20492054, 2010.

[157] P. Olgiati, A. Politis, P. Malitas et al., "APOE epsilon4 allele and cytokine production in Alzheimer's disease," International Journal of Geriatric Psychiatry, vol. 25, no. 4, pp. 338-344, 2010. 
[158] H. Hayashi, R. B. Campenot, D. E. Vance, and J. E. Vance, "Apolipoprotein E-containing lipoproteins protect neurons from apoptosis via a signaling pathway involving lowdensity lipoprotein receptor-related protein-1," Journal of Neuroscience, vol. 27, no. 8, pp. 1933-1941, 2007.

[159] I. P. Trougakos, M. Lourda, M. H. Antonelou et al., "Intracellular clusterin inhibits mitochondrial apoptosis by suppressing p53-activating stress signals and stabilizing the cytosolic Ku70-bax protein complex," Clinical Cancer Research, vol. 15, no. 1, pp. 48-59, 2009.

[160] R. A. Nixon, A. M. Cataldo, and P. M. Mathews, "The endosomal-lysosomal system of neurons in Alzheimer's disease pathogenesis: a review," Neurochemical Research, vol. 25, no. 9-10, pp. 1161-1172, 2000.

[161] A. M. Cataldo, S. Petanceska, N. B. Terio et al., "A $\beta$ localization in abnormal endosomes: association with earliest $\mathrm{A} \beta$ elevations in $\mathrm{AD}$ and Down syndrome," Neurobiology of Aging, vol. 25, no. 10, pp. 1263-1272, 2004.

[162] A. M. Cataldo, C. M. Peterhoff, J. C. Troncoso, T. GomezIsla, B. T. Hyman, and R. A. Nixon, "Endocytic pathway abnormalities precede amyloid $\beta$ deposition in sporadic Alzheimer's disease and down syndrome: differential effects of APOE genotype and presenilin mutations," The American Journal of Pathology, vol. 157, no. 1, pp. 277-286, 2000.

[163] E. L. Eskelinen, "Maturation of autophagic vacuoles in mammalian cells," Autophagy, vol. 1, no. 1, pp. 1-10, 2005.

[164] W. H. Yu, A. Kumar, C. Peterhoff et al., "Autophagic vacuoles are enriched in amyloid precursor protein-secretase activities: implications for $\beta$-amyloid peptide over-production and localization in Alzheimer's disease," International Journal of Biochemistry and Cell Biology, vol. 36, no. 12, pp. 2531-2540, 2004.

[165] B. Boland, D. A. Smith, D. Mooney, S. S. Jung, D. M. Walsh, and F. M. Platt, "Macroautophagy is not directly involved in the metabolism of amyloid precursor protein," Journal of Biological Chemistry, vol. 285, no. 48, pp. 37415-37426, 2010.

[166] C. He and D. Klionsky, "Regulation mechanisms and signaling pathwas of autophagy," Annual Review of Genetics, vol. 43, pp. 67-93, 2009.

[167] S. F. Funderburk, B. K. Marcellino, and Z. Yue, "Cell "self-eating” (autophagy) mechanism in Alzheimer's disease," Mount Sinai Journal of Medicine, vol. 77, no. 1, pp. 59-68, 2010.

[168] N. Ertekin-Taner, "Genetics of Alzheimer disease in the preand post-GWAS era," Alzheimer's Research and Therapy, vol. 2, no. 1, article 3, pp. 1-12, 2010.

[169] K. S. Kendler, “'A gene for...': the nature of gene action in psychiatric disorders," The American Journal of Psychiatry, vol. 162, no. 7, pp. 1243-1252, 2005.

[170] L. Franke, H. van Bakel, L. Fokkens, E. D. de Jong, M. Egmont-Petersen, and C. Wijmenga, "Reconstruction of a functional human gene network, with an application for prioritizing positional candidate genes," The American Journal of Human Genetics, vol. 78, no. 6, pp. 1011-1025, 2006.

[171] A. M. Barrett, "Probable Alzheimer's disease: gender-related issues," The Journal of Gender-Specific Medicine, vol. 2, no. 1, pp. 55-60, 1999.

[172] M. Musicco, "Gender differences in the occurrence of Alzheimer's disease," Functional Neurology, vol. 24, no. 2, pp. 89-92, 2009.

[173] H. Xu, R. Wang, Y. W. Zhang, and X. Zhang, "Estrogen, $\beta$-amyloid metabolism/trafficking, and Alzheimer's disease," Annals of the New York Academy of Sciences, vol. 1089, pp. 324-342, 2006.
[174] C. G. Lyketsos, J. M. E. Sheppard, M. Steinberg et al., "Neuropsychiatric disturbance in Alzheimer's disease clusters into three groups: the Cache County Study," International Journal of Geriatric Psychiatry, vol. 16, no. 11, pp. 1043-1053, 2001.

[175] S. H. Ryu, C. Katona, B. Rive, and G. Livingston, "Persistence of and changes in neuropsychiatric symptoms in Alzheimer disease over 6 months: the LASER-AD study," The American Journal of Geriatric Psychiatry, vol. 13, no. 11, pp. 976-983, 2005.

[176] M. C. McCulley, I. N. M. Day, and C. Holmes, "Association between interleukin 1- $\beta$ promoter $(-511)$ polymorphism and depressive symptoms in Alzheimer's disease," American Journal of Medical Genetics, vol. 124, no. 1, pp. 50-53, 2004.

[177] D. Craig, D. J. Hart, K. McCool, S. P. McIlroy, and A. P. Passmore, "The interleukin $1 \beta$ gene promoter polymorphism $(-511)$ acts as a risk factor for psychosis in Alzheimer's dementia," Annals of Neurology, vol. 56, no. 1, pp. 121-124, 2004.

[178] A. Serretti, P. Olgiati, A. Politis et al., "Lack of association between interleukin-1 alpha rs1800587 polymorphism and Alzheimer's disease in two independent European samples," Journal of Alzheimer's Disease, vol. 16, no. 1, pp. 181-187, 2009.

[179] M. A Demichele-Sweet, L. Klei, B. Devlin et al., "No association of psychosis in Alzheimer disease with neurodegenerative pathway genes," Neurobiology of Aging, vol. 32, no. 3, pp. 555.e9-555.e11, 2011.

[180] S. Seshadri, A. L. de Stefano, R. Au et al., "Genetic correlates of brain aging on MRI and cognitive test measures: a genome-wide association and linkage analysis in the framingham study," BMC Medical Genetics, vol. 8, supplement 1, 2007.

[181] K. Beyer, J. I. Lao, P. Latorre, and A. Ariza, "Age at onset: an essential variable for the definition of genetic risk factors for sporadic Alzheimer's disease," Annals of the New York Academy of Sciences, vol. 1057, pp. 260-278, 2005.

[182] C. Babiloni, L. Benussi, G. Binetti et al., "Genotype (cystatin C) and EEG phenotype in Alzheimer disease and mild cognitive impairment: a multicentric study," NeuroImage, vol. 29, no. 3, pp. 948-964, 2006.

[183] J. Infante, C. Sanz, J. L. Fernández-Luna, J. Llorca, J. Berciano, and O. Combarros, "Gene-gene interaction between interleukin- 6 and interleukin-10 reduces AD risk," Neurology, vol. 63, no. 6, pp. 1135-1136, 2004.

[184] M. Bagli, A. Papassotiropoulos, F. Jessen, M. L. Rao, W. Maier, and R. Heun, "Gene-gene interaction between interleukin- 6 and $\alpha 2$-macroglobulin influences the risk for Alzheimer's disease," Annals of Neurology, vol. 47, no. 1, pp. 138-139, 2000.

[185] J. M. Kim, R. Stewart, S. W. Kim et al., "Methylenetetrahydrofolate reductase gene and risk of Alzheimer's disease in Koreans," International Journal of Geriatric Psychiatry, vol. 23, no. 5, pp. 454-459, 2008.

[186] R. J. Haasl, M. R. Ahmadi, S. V. Meethal et al., "A luteinizing hormone receptor intronic variant is significantly associated with decreased risk of Alzheimer's disease in males carrying an apolipoprotein E $\varepsilon 4$ allele," BMC Medical Genetics, vol. 9, article 37, 2008.

[187] B. Wang, F. Jin, Z. Yang et al., "The insertion polymorphism in angiotensin-converting enzyme gene associated with the APOE $\& 4$ allele increases the risk of late-onset Alzheimer disease," Journal of Molecular Neuroscience, vol. 30, no. 3, pp. 267-271, 2006. 
[188] S.-C. Wang, B. Oeize, and A. Schumacher, "Age-specific epigenetic drift in late-onset Alzheimer's disease," PLOS ONE, vol. 3, no. 7, Article ID e2698, 2008.

[189] D. Mastroeni, A. McKee, A. Grover, J. Rogers, and P. D. Coleman, "Epigenetic differences in cortical neurons from a pair of monozygotic twins discordant for Alzheimer's disease," PLoS ONE, vol. 4, no. 8, Article ID e6617, 2009.

[190] N. H. Zawia, D. K. Lahiri, and F. Cardozo-Pelaez, "Epigenetics, oxidative stress, and Alzheimer disease," Free Radical Biology and Medicine, vol. 46, no. 9, pp. 1241-1249, 2009.

[191] R. Cacabelos, "Pharmacogenomics and therapeutic prospects in dementia," European Archives of Psychiatry and Clinical Neuroscience, vol. 258, supplement 1, pp. 28-47, 2008. 


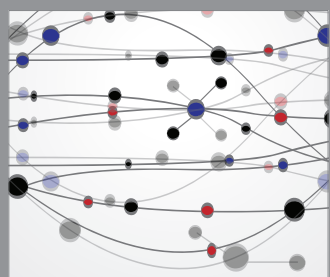

The Scientific World Journal
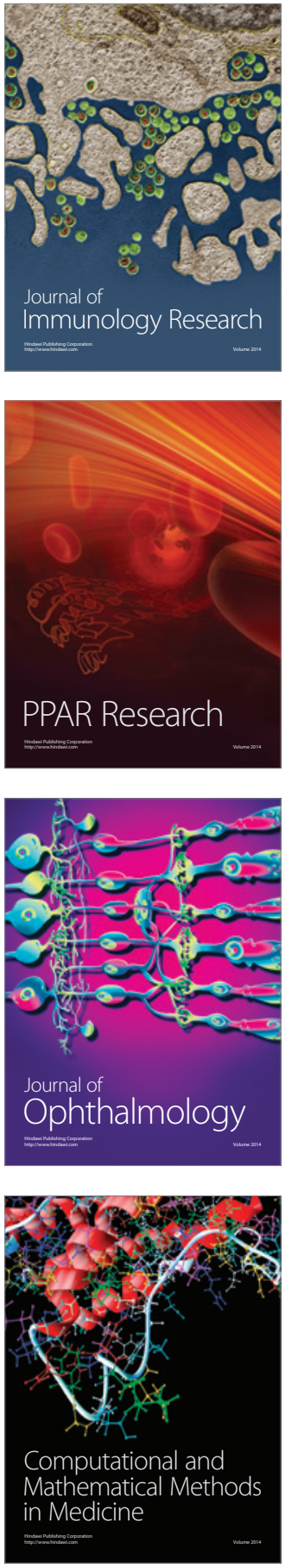

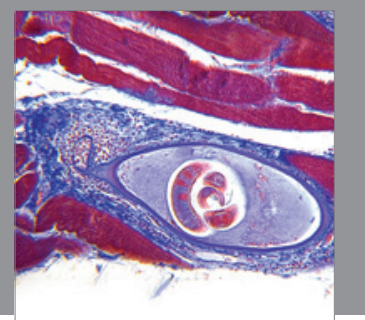

Gastroenterology

Research and Practice
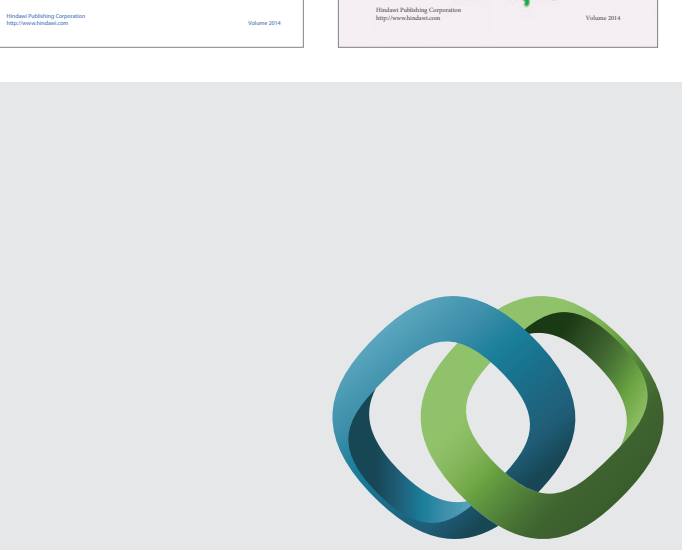

\section{Hindawi}

Submit your manuscripts at

http://www.hindawi.com
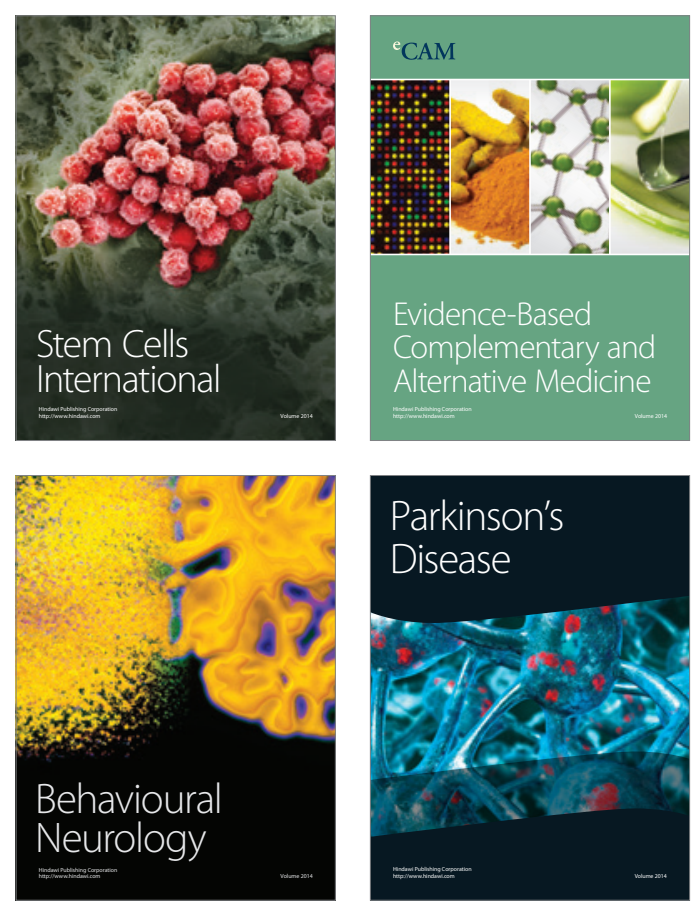

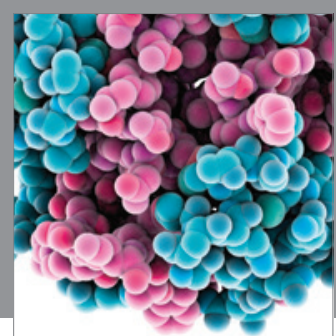

Journal of
Diabetes Research

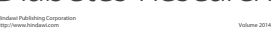

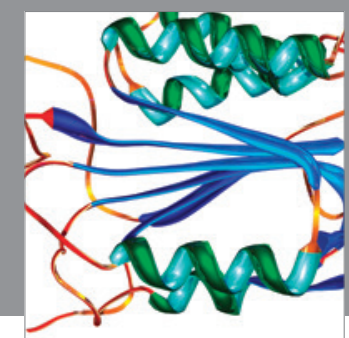

Disease Markers
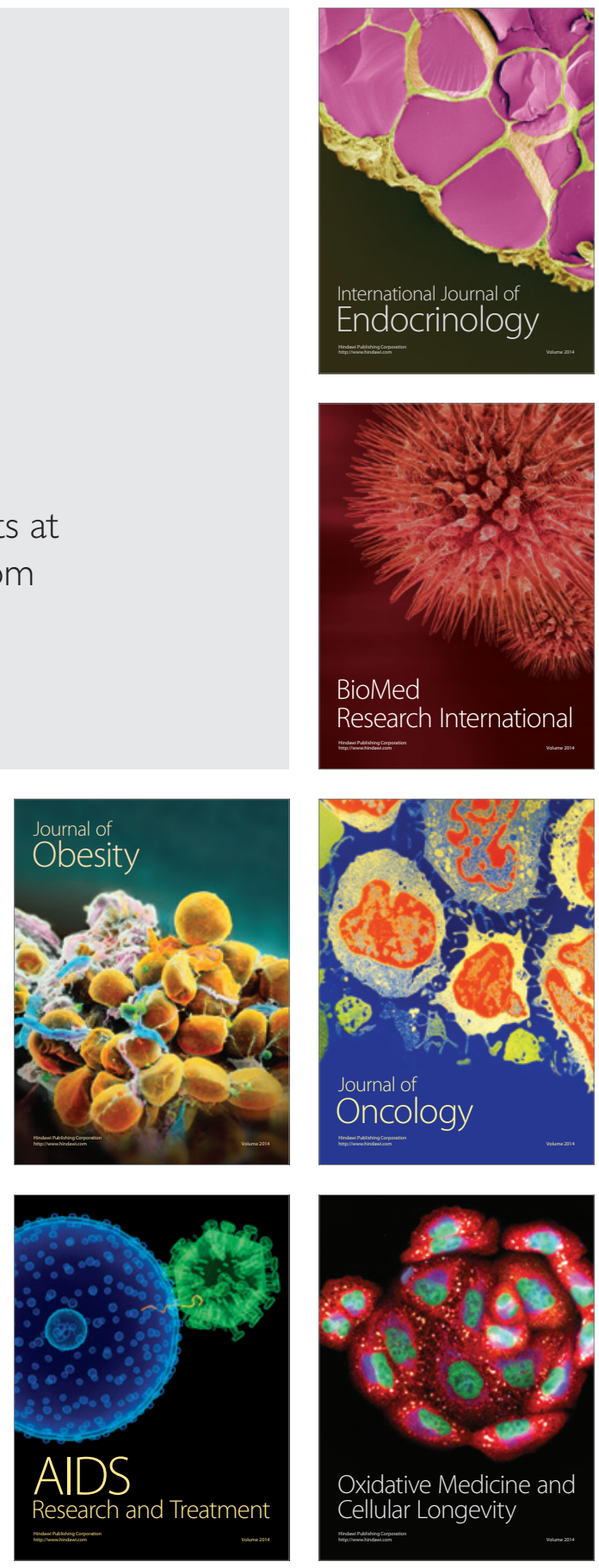